\title{
Forum Commission Enforcement of Foreign Workmen's Compensation Acts
}

Multistate cases involving claims for workmen's compensation have traditionally been treated differently from multistate cases in contract or tort. Because most workmen's compensation statutes provide for exclusive administration by a special commission, ${ }^{1}$ courts have held that rights under these statutes are unenforceable outside the state of enactment. ${ }^{2}$ Commission administration has been thought to be a "special remedy" incapable of approximation by state courts; ${ }^{3}$ hence the right of recovery under these statutes has been thought unenforceable since the relief granted cannot be substantially the same. ${ }^{4}$ Conse-

1 E.g., Cal. Labor Code \& 60; Del. Code Ann. tit. 19, § 2121 (1953); Ill. ANN. Stat. ch. 48, \& 155 (Smith-Hurd 1960); Mrch. Stat. ANn. § 17.190 (1960). See also Restatement (SECOND), CoNfLICT of LAws $\S 167$ (Tent. Draft No. 9, 1964) [hereinafter cited as RESTATEMENT SECOND]. Throughout this comment the term "commission" refers to any state body or individual other than the courts which administers that state's workmen's compensation act. Also, the term "enforcement" means administration of claims under a workmen's compensation act rather than enforcement of an award under an act.

2 Green v. J.A. Jones Const. Co., 161 F.2d 359 (5th Cir. 1947); Elliott v. De Soto Crude Oil Purchasing Corp., 20 F. Supp. 743 (W.D. La. 1937); Logan v. Missouri Valley Bridge \&. Iron Co., 157 Ark. 528, 249 S.W. 21 (1923); Davis v. Swift \& Co., 175 Tenn. 210, 133 S.W.2d 483 (1939). Contra, Employers' Liability Assur. Corp. v. Warren, 172 Tenn. 403, 112 S.W.2d 837 (1938). See generally 2 LARson, WORKMEN's CoMpensation LAW § 84.20 (1961); Malone \& Plant, Workmen's Compensation 532 (1963); Note, Enforcement in One Jurisdiction of Right to Compensation Under Workmen's Compensation Act of Another Jurisdiction, 6 VAND L. REv. 744 (1953).

3 Specifically, provisions for commission enforcement have been regarded as special remedies integrally related to the rights of recovery and incapable of approximation by the foreign forum. E.g., Green v. J. A. Jones Const. Co., 161 F.2d 359 (5th Cir. 1947). In Green, the Fifth Circuit denied a Louisiana federal district court jurisdiction over an action to enforce the Georgia Workmen's Compensation Act. The court held that because the Georgia act provided for an exclusive administrative remedy, the Louisiana courts were barred from enforcing the act: "[W]here the provision for the liability claimed is coupled with a provision for a special remedy to be afforded not by a court but by a commission, that remedy and that alone must be employed and resort to court action may not be had for relief." Ibid. The language of the Fifth Circuit in Green should be compared to that used by the Supreme Court in Tennessee Coal Co. v. George, 233 U.S. 354 (1914), discussed in note 18 infra.

4 However, state courts will usually enforce rights under court-administered foreign workmen's compensation acts. See Texas Pipe Line Co. v. Ware, 15 F.2d 17 (8th Cir.), cert. denied, 278 U.S. 742 (1926); Lindberg v. So. Cas. Co., 15 F.2d 54 (S.D. Tex. 1926), $a f f d$ sub nom. United Dredging Co. v. Lindberg, 18 F.2d 453 (5th Cir.), cert. denied, 274 U.S. 759 (1927); Floyd v. Vicksburg Cooperage Co., 156 Miss. 567, 126 So. 395 (1930). 
quently, the principal conflict of laws question in workmen's compensation cases traditionally has been whether the forum state can afford relief to the claimant under its own compensation act. ${ }^{5}$

The refusal of state courts to enforce rights under commission-administered foreign workmen's compensation acts may have appeared to be constitutionally sanctioned, if not compelled, by the full faith and credit clause. ${ }^{b}$ If enforcement by a specially created foreign commission is an integral part of the right to compensation, enforcement by a state court fails to meet the requirement that full faith and credit be extended to the acts of other states. ${ }^{\top}$ This ostensible bar to enforcement of foreign workmen's compensation acts was weakened, however, in Crider v. Zurich Insurance Co., ${ }^{8}$ where the Supreme Court held that courts of a state with an interest in the claim may enforce rights under foreign commission-administered workmen's compensation acts without violating the full faith and credit clause.

Crider prompts a re-examination of situations in which a foreign workmen's compensation act is found to be the controlling law. ${ }^{9}$ The

Contra, Martin v. Kennecott Copper Corp., 252 Fed. 207 (W.D. Wash. 1918); Mosely v. Empire Gas \& Fuel Co., 313 Mo. 225, 281 S.W. 762 (1926). States which administer their acts through the courts are Alabama, Louisiana, New Mexico, Tennessee, and Wyoming. U.S. Bureau of Labor Statistics, Dep'T of LABor, Bull. No. 161, at 69 (1960).

5 EhrENZWEig, CoNflict of LAws \$ 228, at 604 (1962); RESTATEMENT, SECOND 167: "[T]he principal problem in the area is not one of choice of law but rather what is the range of application to persons and things without the state that will be given by a state to its own workmen's compensation act."

6 "Full Faith and Credit shall be given in each State to the public Acts, Records, and judicial Proceedings of every other State." U.S. Const. art. IV, \& 1.

7 Tennessee Coal Co. v. George, 233 U.S. 354, 359 (1914); Atchison, T. \& S.F. Ry. v. Sowers, 213 U.S. 55 (1909); cf. Pearson v. Northeast Airlines, Inc., 309 F.2d 553, 557 (2d Cir. 1962).

8380 U.S. 39 (1965). The case is discussed in 2 LARSON, WORKMEN'S CoMPENSATION \$ 84.20, at 435-37 (Supp. 1965); Greenspan, Crider v. Zurich Insurance Company: Decline of Conceptualism in the Conflict of Laws, 27 U. PrTt. L. REv. 49 (1965); 7 Boston College INDUSTRIAL \& COMMERCIAL L. REv. 174 (1965); 33 FordHAM L. REv. 713 (1965).

9 Assuming that both forum and foreign law may be applied to a multistate workmen's compensation case, foreign law may be held to be controlling for a variety of reasons. Under the traditional approach to multistate workmen's compensation cases, liability was characterized as either tortious or contractual. Under the tort analysis, foreign law would be the relevant law whenever the injury occurs outside the forum. See, e.g., Gould's Case, 215 Mass. 480, 102 N.E. 693 (1913). Where workmen's compensation is characterized as contractual, the controlling act will be that which governs the contract of employment. Thus a state where the contract of employment is made may afford relief under its own compensation act despite the injury's occurrence outside the state. See cases cited in Dwan, Workmen's Compensation and the Conflict of Laws, 11 MINN. L. REv. 329, 337-38 n.34 (1927). On the other hand, a state may choose to refuse relief under its own act when the injury occurred within the state but the contract was made elsewhere. Hall v. Commission, 77 Colo. 338, 235 Pac. 1073 (1925). Because both the traditional tort and contract 
Court in Crider was concerned with whether an interested forum is constitutionally compelled to dismiss the case. Other problems, which the Court did not consider, are whether the forum is constitutionally compelled to assume jurisdiction over the $\operatorname{case}^{10}$ and whether the forum

approaches tend to be restrictive, often denying a state with a substantial interest in the injury the opportunity to afford relief to a claimant, these approaches have been largely abandoned. See RESTATEMENT SECOND § 398, at 170-71.

The most prevalent approach is that of the Restatement, which advocates that relief be obtained under the workmen's compensation act of the state which has had most significant relationship to the employment. Id. at 171 . To determine which state has the most significant relationship, a number of factors must be considered: (1) where the injury occurred; (2) where the contract of employment was entered into; (3) where the employment relationship exists or is carried out; (4) where the industry is located; (5) where the employee resides; and (6) whose statute the parties expressly adopted by contract. As the Restatement notes, states differ as to which factor should weigh most heavily in selecting the state of most significant relationship. Generally, occurrence of the injury within the state will suffice for applying the local act. See, e.g., Pacific Employers Ins. Co. v. Commission, 306 U.S. 493 (1939) (permitting application of California's workmen's compensation act to an injury occurring within the state, even though the employee was a Massachusetts resident, regularly employed there by a Massachusetts corporation, and covered by the Massachusetts workmen's compensation act, which purported to be exclusive of all other remedies). See also 2 LARSON, WORKMEN's COMPENSATION 375 (1961). However, courts have reached no such consensus on the other factors. See, e.g., Cardillo v. Liberty Mut. Ins. Co., 330 U.S. 469 (1947) (workmen's compensation act of employee's domicile may be applied where both injury and contract outside forum); Duskin v. Pennsylvania-Central Airlines Corp., 167 F.2d 727 (6th Cir.), cert denied, 335 U.S. 829 (1948) (agreement of the parties that their rights to be determined by state's workmen's compensation found conclusive); Stansberry v. Monitor Stove Co., 150 Minn. 1, 183 N.W. 977 (1921) (place of employer's business establishment from which employee's work directed and supervised stressed).

Still another approach which may be utilized is that suggested by Professor Brainerd Currie in B. Currie, The Constitution and the Choice of Law: Governmental Interests and the Judicial Function, 26 U. CHI. L. REv. 9 (1958), reprinted in B. CuRruE, SELEcted Essays on the Conflict of LAws 188-282 (1963). Professor Currie suggests that a state with any governmental interest in a multistate action before it should apply its own law. A state has such a governmental interest when the social, economic, or administrative policy as expressed by its law would be advanced by applying that law to the case before it. The Currie approach differs from the Restatement in that the forum's law is considered first, and if it is determined that the forum has an interest in affording relief, its law is applied regardless of the interest a foreign state may have in the case.

Of the various approaches, the Restatement appears to be the fairest to the states concerned, since it is most appreciative of the relationship between workmen's compensation legislation and the employment status. Because of this appreciation it seems least likely to impose any hardship on the parties; it affords to a forum a broad range of valid considerations in determining the relevant law. See generally 2 LARson, op. cit. supra at 368-75; Dwan, supra at 26-32; Hill, Governmental Interest and Judicial Function-A Reply to Professor Currie, 27 U. CHr. L. REv. 463 (1960).

10 The Court in Crider actually had the opportunity to decide this question, since the Alabama court, in allowing the suit, had contravened state law which prohibited such actions. Thus the Court could have decided whether a state law forbidding entertainment of suits under commission-administered foreign workmen's compensation acts conflicted with the full faith and credit clause. For a discussion of the Alabama law, see note 17 infra. 
as a matter of its own policy should assume jurisdiction over the case.11

This comment will consider the constitutional limitations upon a state's power to dismiss a case arising under a foreign workmen's compensation act, and the relevant considerations for exercising that power. ${ }^{12}$ The comment concludes that states having an interest in the injury should hear claims under foreign workmen's compensation acts, even though they are not constitutionally compelled to do so, and that enforcement can be best effectuated by the forum state's workmen's compensation commission rather than its courts.

\section{Is the Forum Constitutionally Compelled To Dismiss the Case?}

In Crider an Alabama resident sued his employer, a Georgia corporation, in an Alabama state court for an injury sustained in Alabama.

11 This comment will consider only the possibility of state court enforcement of foreign workmen's compensation acts, although federal courts may acquire diversity jurisdiction over workmen's compensation actions when the claim is brought in one state under the act of another. 28 U.S.C. \& 1445(c) (1964); IA MOORE, FEDERAL PrActice If 0.167(6) n.4, at 963 (Supp. 1965). Federal courts, like state courts, have traditionally dismissed actions in which the workmen's compensation act sought to be enforced is commission-administered. Green v. J.A. Jones Const. Co., 161 F.2d 359 (5th Cir. 1947); Shultz v. Lion Oil Co., 106 F. Supp. 119 (D.C. Ark. 1952); Snook v. Commission, 9 F. Supp. 26 (D.C. Ill. 1934). Presumably, the holding in Crider permits federal as well as state courts to assume jurisdiction over commission-administered workmen's compensation acts; however, the practical obstacles which state courts may avoid in enforcing such foreign causes of action will continue to discourage federal courts from enforcing rights under commissionadministered workmen's compensation acts. Whereas state courts may be able to utilize their state workmen's compensation commissions, this option is not available to the federal courts. Thus Crider should have little impact upon workmen's compensation cases brought before federal courts.

On the subject of workmen's compensation claims in the federal courts, see generally MOORE, op. cit. supra at II 0.157(4-9), 0.167(6); Wallace, Are Workmen's Compensation Cases Triable in Federal District Courts? 7 LA. L. Rev. 350 (1947); Annot., 60 A.L.R.2d 1262 (1958).

12 Only situations in which the forum has an interest in the action have been discussed. Although analytically the argument for entertaining suits under foreign workmen's compensation acts by interested forums might apply equally well to disinterested forums, enforcement by disinterested forums raises many additional diffculties. First, the disinterested forum may be constitutionally precluded from applying its own law. See Home Ins. Co. v. Dick, 281 U.S. 397 (1930). Second, Crider offers no support for such an extension; the holding is limited to states having "a concern in the problems following in the wake of the injury." Crider v. Zurich Ins. Co., 380 U.S. 39, 41 (1965), quoting Carroll v. Lanza, 349 U.S. 408, 413 (1954). Third, it is doubtful that as a practical matter a disinterested forum would assume the burden of applying a foreign workmen's compensation act. Rather, it might be proper in this instance for the forum to dismiss the action to free its courts or commission from unnecessary litigation. Lastly, where the forum has no interest in the action, the desire for uniform interpretation of a state's workmen's compensation act outweighs any convenience the forum may offer the plaintiff and justifies dismissal of the action. 
The action was brought under the Georgia Workmen's Compensation Act, which provides for exclusive enforcement by a Georgia commission. ${ }^{13}$ The Alabama court entered a default judgment against the employer; but when the claimant sought to enforce his judgment in a subsequent Alabama proceeding, the second Alabama court refused enforcement on the ground that the first court lacked subject matter jurisdiction to enforce the Georgia act. ${ }^{14}$ The federal district court in Alabama also refused to enforce the judgment, holding that the Alabama courts lacked subject matter jurisdiction over the action because of the exclusive administrative remedy of the Georgia act. ${ }^{15}$ The court of appeals affirmed per curiam. ${ }^{16}$ The Supreme Court reversed and remanded to the court of appeals for reconsideration of its holding "free from any supposed constitutional compulsion." 17

\footnotetext{
13 GA. CODE ANN. \& 114-103 (1956).

14380 U.S. at 44 (dissenting opinion).

15224 F. Supp. 87, 88 (D.C. Ala. 1963).

16324 F.2d 499 (5th Cir. 1963).
}

17380 U.S. at 43. As Mr. Justice Goldberg points out in his dissent and as the decision on remand makes clear, the case could have been decided on state grounds. On remand, the court of appeals affirmed its prior decision, holding that Alabama law rather than constitutional considerations prohibited the assumption of jurisdiction over a suit involving the Georgia Workmen's Compensation Act. Crider v. Zurich Ins. Co., 348 F.2d 211 (5th Cir. 1965), cert denied, 382 U.S. 1000 (1966). The court relied on Singleton v. Hope Eng'r. Co., 273 Ala. 538, 137 So. 441 (1981), in which the court sustained a demurrer to a complaint alleging that the plaintiff's employer had breached a duty under the Georgia Workmen's Compensation Act, and held that under both Georgia and Alabama law it had no jurisdiction to enforce the right since the remedy was vested exclusively with the Georgia Workmen's Compensation Commission.

While Singleton represents the current Alabama law on enforcement of rights under foreign workmen's compensation acts, it should be more narrowly construed in light of Crider. It can be distinguished from Crider on several grounds. The injury in Singleton occurred in Georgia, and it is not even clear that the claimant was an Alabama resident. Thus, Alabama's interest in granting relief in Singleton was minimal. More importantly, in Singleton the claimant had already been compensated under the Georgia act in Georgia. The court merely refused to hear a claim for common law damages where liability was predicated on the Georgia compensation act and where the plaintiff had already recovered his statutory compensation.

Singleton should be distinguished because the reasoning of the opinion is unsound. The court concluded that the exclusive remedy provision of the Georgia act effectively precluded relief under that statute except from the Georgia commission. Yet the Court in Crider affirmed the freedom of an interested forum to afford relief under a foreign workmen's compensation act. As Mr. Justice Douglas stated in his majority opinion in Carroll v. Lanza, 349 U.S. 408, 413-44 (1954) and repeated in writing for the majority in Crider: "Missouri can make her Compensation Act exclusive, if she chooses, and enforce it as she pleases within her borders. Once that policy is extended into other States, different considerations come into play. Arkansas can adopt Missouri's policy if she likes. Or, as the Pacific Employers Insurance Co. case teaches, she may supplement or displace it with another, insofar as remedies for acts occurring within her boundaries are concerned." 380 U.S. at 41. Thus, although the Fifth Circuit in Crider correctly followed a state conflicts rule which denies the Alabama courts jurisdiction over cases arising under the Georgia act, the rule 
The constitutional issue resolved by the Court was whether the full faith and credit clause bars an interested state's enforcement of a foreign workmen's compensation statute which is administered exclusively by a special commission. ${ }^{18}$ In Crider the Court dispelled any belief that this result was compelled by the full faith and credit clause by explicitly approving the adoption of the liability provisions of a foreign workmen's compensation act by an interested state while ignoring the provisions concerning the procedure for determining liability. ${ }^{19}$ In the Court's words: "[T] 'displace' the remedy of the other State, consistently with constitutional requirements." 20

Although the question in earlier multistate workmen's compensation cases before the Court had been whether an interested state could apply its own compensation act where a foreign statute purported to be an exclusive remedy, ${ }^{21}$ and not whether the state could impose liability under the foreign act, ${ }^{22}$ the holding in Crider is a logical development

itself is archaic after the Supreme Court's decision in Crider and should be reformulated by the Alabama courts.

18 The principle that special remedy provisions preclude enforcement by other states appeared to be given constitutional sanctity in Tennessee Coal Co. v. George, 233 U.S. 354 (1914), where the Court upheld a Georgia court's enforcement of an Alabama law imposing liability upon employers for injuries caused their employees by defective machinery. The Alabama employer argued that the act limited jurisdiction to courts within the state and that the Georgia courts were therefore barred by the full faith and credit clause from enforcing the act. The Court answered that Alabama, by entrusting enforcement of the act to its courts, had created a transitory cause of action enforceable in any court having jurisdiction over the parties. In a famous dictum, however, Mr. Justice Lamar noted that "there are many cases where right and remedy are so united that the right cannot be enforced except in the manner and before the tribunal designated by the act. For the rule is well settled that 'where the provision for the liability is coupled with a provision for a special remedy, that remedy, and that alone, must be employed.' "Id. at 359.

19 Cf. Pearson v. Northeast Airlines, Inc., 309 F.2d 554 (2d Cir. 1962), where the Second Circuit imposed liability under the Massachusetts' wrongful death statute but rejected Massachusetts' $\$ 15,000$ limitation on liability in favor of the New York policy of unlimited liability. In a strong dissent, however, Judge Friendly argued that the damage limitation was a substantial provision of the right which could not be ignored if Massachusetts law were to be applied. 309 F.2d at 564-69. See note 35 infra and accompanying text.

20380 U.S. at 42.

21 Carroll v. Lanza, 349 U.S. 408 (1954) (Arkansas, the state where the injury occurred, permitted to award common law damages to an employee against a third party, even though the employee was barred from bringing the action by the exclusive workmen's compensation act of Missouri, his residence, under which he had already received partial compensation for his injury); Pacific Employers Ins. Co. v. Commission, 306 U.S. 493 (1938), supra note 9; Alaska Packers Ass'n v. Commission, 294 U.S. 532 (1935) (California permitted to apply her compensation act to an injured resident when the contract of employment had been made in California and employer was a California corporation, even though the injury had occurred in Alaska and the employee and employer had agreed to be bound by the exclusive Alaska workmen's compensation act).

22 Grider v. Zurich Ins. Co., 380 U.S. 39, 45 (1965) (dissenting opinion). 
in the evolution of the Court's attitude toward the extraterritorial effect of workmen's compensation laws. In the former cases the Court held that an interested state may apply its own workmen's compensation law. The corollary in Crider is that the state may pattern its law on foreign law: it may determine liability under the foreign workmen's compensation law without adopting other provisions of the law. ${ }^{23}$

In contrast to the prior multistate workmen's compensation cases, Crider increases the possibility that commission-administered workmen's compensation acts will control work injuries in actions brought outside the state. Prior to Crider, in a multistate workmen's compensation action, an interested forum wishing to entertain the claim could do so only by applying its own law. Consequently, forum law was applied even where the interest of the forum was clearly outweighed by that of another state. ${ }^{24}$ Under Crider, an interested state may entertain the action even when foreign law is found to control. Consequently, an interested forum in a multistate workmen's compensation action not wishing to dismiss the case is now free to make a rational choice of controlling law, rather than having to strain to find its own law applicable.

\section{Is the Forum Constitutionally Compelled To Assume JuRISDiction Over the CASE?}

The analysis thus far has assumed that the forum wishes to afford relief under the foreign workmen's compensation act. However, the difficulties of construing and administering the foreign act make it likely that in many cases the forum will not want to consider a case once foreign law is found to control.

On occasion, the full faith and credit clause has been used to compel a state to enforce rights under the legislation of another state. ${ }^{25}$ In

23380 U.S. at 42. See also Pearson v. Northeast Airlines, Inc., 309 F.2d 554 (1962), affirming the imposition of liability by a New York court under the Massachusetts wrongful death statute: "We believe that in [imposing liability in accordance with the Massachusetts act] ... New York is not bound to model all of the rules governing this litigation in which it is conceded it has a legitimate interest, on Massachusetts law. We are convinced that New York may examine each issue in the litigation-the conduct which creates liability, the parties who may bring an action, the extent of liability, the period during which the liability may be sued upon, and in appropriate cases, matters of immunity, insurance procedure, etc.-and by weighing the contacts of various states with the transaction, New York may, without interfering with the Constitution, shape its rules controlling the litigation." 309 F.2d at 560-61.

24 See, e.g., Pacific Employers Ins. Co. v. Commission, 306 U.S. 493 (1938); cases cited note 9 supra.

25 E.g., Order of Travelers v. Wolfe, 331 U.S. 586 (1947) (forum required to give full faith and credit to law of the state of incorporation allowing fraternal benefit society to limit duration of its liability); John Hancock Ins. Co. v. Yates, 299 U.S. 178 (1936) (state 
Hughes $v$. Fetter ${ }^{26}$ the Wisconsin courts dismissed a suit based on a sister state's wrongful death statute. Wisconsin was the state of residence of all the parties involved, but the death had occurred in Illinois. Wisconsin's wrongful death statute limited recovery to deaths occurring within the state, and the Wisconsin courts construed this provision as prohibiting them from entertaining all actions involving wrongful deaths occurring outside the state. The Supreme Court, reversing the dismissal, held that Wisconsin must yield to the "strong unifying principle embodied in the Full Faith and Credit Glause looking toward maximum enforcement in each state of the obligations of rights created or recognized by the statutes of sister states."27

Hughes, although a wrongful death action, presented a situation quite similar to a multistate workmen's compensation case. In Hughes, Wisconsin, as the home of all the parties, could not predicate dismissal on forum non conveniens grounds. In addition, the Wisconsin court found Illinois law controlling, although the local law could constitutionally have been applied. Lastly, the forum had no antagonism to wrongful death actions in general, and thus the case can be distinguished from those in which refusal to enforce the foreign cause of action was predicated upon the repugnance of the foreign statute to the forum's policy. ${ }^{28}$ The critical issue is whether the same reasoning might be applied to compel a reluctant state court to enforce rights under a foreign workmen's compensation act.

The Court in Hughes found that Wisconsin's rule against entertaining actions under foreign wrongful death statutes did not further any

required to give full faith and credit to sister state's parol evidence statute which prevented recovery on insurance contract); Broderick v. Rosner, 294 U.S. 629 (1935) (state required to open its courts to stockholders' liability suits based on law of a foreign state). See generally Hughes v. Fetter, 341 U.S. 609, 614-21 (1951) (dissenting opinion); B. Currie, The Constitution and the "Transitory" Cause of Action (pts. 1-2), 73 HARv. L. REv. 36, 268 (1959), in B. CURrie, Selected Essays on the Conflict of Laws 283 (1963).

26341 U.S. 609 (1951).

27 Id. at 612 .

28 See Bothwell v. Buckbee, Mears Co., 275 U.S. 274 (1927) (state may refuse to enforce insurance contract made in a foreign state where contract contemplates performance by insurance company of acts forbidden by forum's law); Union Trust Co. v. Grosman, 245 U.S. 412 (1918) (Texas not compelled to enforce married woman's guaranty of husband's note against her separate property where guaranty was executed in Illinois but enforcement would be contrary to public policy of Texas). A state may also refuse to entertain a cause of action based on the law of another state when it is closely connected with the governmental authority of a foreign state, such as actions for penalties or claims for taxes. Huntington v. Attrill, 146 U.S. 657 (1892); see Milwaukee County v. M. E. White Co., 296 U.S. 268 (1935); Moore v. Mitchell, 281 U.S. 18 (1930). See generally Paulsen \& Sovern, "Public Policy" in the Conflict of Laws, 56 CoLum. L. Rev. 969 (1956). 
legitimate Wisconsin interest. ${ }^{29}$ When, however, a state's refusal to entertain a foreign cause of action is not arbitrary but rather consistent with efficient conduct of its judicial business, the dismissal will be upheld. For example, in Wells $v$. Simonds Abrasive Co., ${ }^{30}$ the Court held that the Pennsylvania one year statute of limitations governed a wrongful death action brought in the federal district court in Pennsylvania, even though the action was predicated on the Alabama wrongful death statute, which had a two year statute of limitations. The full faith and credit clause, the Court noted, "merely sets certain minimum requirements which each state must observe when asked to apply the law of a sister state." 31 The Court in Wells distinguished Hughes by noting that the crucial factor in Hughes was that the forum "laid an uneven hand on causes of action arising within and without the forum state."32

Workmen's compensation cases involving dismissal of a cause of action arising under a foreign act would seem analogous to Wells. While claimants who qualify under the domestic workmen's compensation act will be compensated (although not by the courts) and those who qualify under a foreign act will not, this approach to claims under foreign workmen's compensation acts is justified under Hughes and Wells because it is consistent with the forum's policy of freeing its courts from hearing any workmen's compensation claims. It would be ironic indeed if state courts unable to enforce rights under their own workmen's compensation act were compelled by the full faith and credit clause to enforce rights under foreign workmen's compensation acts. In those states whose courts are empowered to enforce their own workmen's compensation acts, however, the full faith and credit clause, under the Hughes doctrine, might compel enforcement of rights under foreign workmen's compensation acts. ${ }^{33}$

29 See Comment, Full Faith and Credit to Statutes of Sister States, 37 CoRNELl L.Q. 441, 457 (1952). See also Reese, Full Faith and Credit to Statutes: The Defense of Public Policy, 19 U. CHI. L. REv. 339 (1952).

30345 U.S. 514 (1953).

$31 \mathrm{Id}$. at 516.

$32 I d$, at 518 .

33 But see B. Currie, op. cit. supra note 9, at 305-06. According to Professor Currie, Hughes involved Wisconsin's arbitrary and capricious discrimination against those of its residents whose deaths resulted from injuries inflicted outside the state. Thus, in Professor Currie's view, the constitutional violation was a denial by a state of the equal protection of the laws, rather than any failure to comply with the full faith and credit clause. Professor Currie concludes that the full faith and credit clause would not require a state to hear foreign causes of action when the refusal to do so is grounded "in good faith upon a policy of promoting the efficiency of the local courts and protecting them from abuse." Id. at 360 . 
III. Should the Forum, as a Matter of Policy, Enforce RIGHTS UNDER A FOREIGN WORKMEN'S COMPENSATION ACT?

If a state is not constitutionally compelled to enforce rights under a foreign workmen's compensation act, the question arises whether the forum state should nonetheless apply that act as a matter of its own policy. This requires an analysis of several factors which are relevant whenever a state is asked to enforce rights under foreign law: (1) the requirements of comity; (2) fairness to the parties; (3) the extra time and cost involved; (4) ability of the forum to afford a substantially similar remedy; (5) ability of the forum to ascertain foreign law.

\section{Comity}

It might be argued that enforcement by the forum of a right created by a foreign statute constitutes an interference with the freedom of the sister state to legislate on matters of domestic concern. If so, comity would require a forum to refuse to enforce rights under the foreign act. $^{34}$ As Judge Friendly noted in objecting to a state's imposing liability under the wrongful death statute of another state while disregarding its limitation on damages:

The terms and conditions of a claim created by statute inevitably reflect the legislature's balancing of those considerations that favor and of those that oppose the imposition of liability. The legislature may be quite unwilling to create the claim on terms allowing it to be enforced without limit of amount as most common law rights can be, or for a period bounded only by statutes of limitation ordinarily applicable. ${ }^{35}$

Judge Friendly's observation on a legislature's unwillingness to create a claim for wrongful death where it is unable to limit the award in a multistate action-an observation of less than universal validity in wrongful death actions ${ }^{36}$ - has little relevance to workmen's compensation liability. Provisions for exclusive administrative enforcement of workmen's compensation claims are not attempts to preclude enforcement of rights under the act outside the state, but rather are based upon intrastate considerations-such as the need for promptness and reduction of expense to the injured workmen. ${ }^{37}$ Several states which

\footnotetext{
34 See Goodrich, Conflict of LAws $\S 7$ (1964). See also Annot., 45 A.L.R. 1223, 1234 (1926).

35 Pearson v. Northeast Airlines, Inc., 309 F.2d 553, 565 (2d Gir. 1962) (dissenting opinion).

38 At least, Massachusetts has not repealed her wrongful death act since Pearson. See Greenspan, supra note 8, at 67-68.

37 DOdd, AdMINISTRATION OF WORKMEN's CoMpensation 99-100 (1936); U.S. BUREAU OF Labor Statistics Dep't of Labor, Bull. No. 161, at 69 (1960).
} 
'originally administered workmen's compensation through the courts abandoned this procedure in favor of administration by commissions, not because they feared that court administration created a transitory cause of action enforceable outside the state, but because judicial machinery proved inadequate to meet the new problems of administration presented by workmen's compensation. ${ }^{38}$

It may be that states would not welcome enforcement of their workmen's compensation acts by other states. ${ }^{39}$ Because of the desire for uniformity through expert, single enforcement, the state whose law is being applied would probably prefer to make the determination of liability. But if the relief granted by the enforcing state will be substantially the same as that which would be granted by the enacting state $^{40}$ a state's fear that its workmen's compensation act will be abused if administered outside the state is unjustified. On the contrary, the interest of the enacting state is being served when its claimant is compensated, while at the same time a limited and determinate liability as prescribed by its act is imposed upon the employer.

\section{Fairness}

Application of the foreign act must be fair to the parties. ${ }^{41}$ For the claimant, the forum in which the action is brought is probably the one most convenient for him. He may favor the forum because of its physical convenience, relative lack of expense, or availability of witnesses. ${ }^{42}$

38 E.g., New Jersey, Minnesota, Kansas, Nebraska, and Rhode Island. See Dodd, op. cit supra note 37 , at $70-83$.

39 See, e.g., Letter from Elmer A. Keller, Administrator, Bureau of Workmen's Compensation, State of Ohio, to the University of Chicago Law Review, April 11, 1966, on file in the Review office, stating that "under no circumstances would we [Ohio] want a foreign jurisdiction interpreting the liberal Ohio Workmen's Compensation Act. . . ." (Emphasis in original).

40 An argument developed infra pp. 191-94.

41 See GOodrich, Confuict of LAWS $\$ 7$ (1964); cf. Floyd v. Vicksburg Cooperage Co., 156 Miss. 567, 126 So. 395 (1930).

42 Evidentiary problems arising in a multistate workmen's compensation action are alleviated somewhat by reciprocity agreements authorizing accommodation hearings among the various states. Under these arrangements, a state workmen's compensation commission holds hearings on any issues designated by the state commission deciding the claim. The hearings are transcribed verbatim and transmitted without comment to the requesting commission for rulings under the relevant law. See Letters from M. Roscoe Lowery, Chairman, State Board of Workmen's Compensation, State of Georgia, May 5, 1966, and Richard E. Moss, Executive Secretary, Industrial Commission of Colorado, April 19, 1966, to the University of Chicago Law Review, on file in the Reyiew office. While in some instances these proceedings are specifically authorized by statute, e.g., ORE. REv. STAT. $\$ 656.128$ (1964), they generally result from informal arrangements among the commissions themselves.

These working agreements do not nullify the need for occasional enforcement of rights under another state's workmen's compensation act. While accommodation hearings 
The defendant or his insurance carrier might be somewhat inconvenienced, but no more so than in those instances when the forum applies its own law. The application of foreign law by the forum would seem to be even fairer to the employer, for at least in this situation he is governed by the law with which he is presumably more familiar.

\section{Costs}

Courts of the forum state must also consider the extra costs involved in applying the foreign statute and the need to avoid congestion. This consideration should not be determinative if, as is probable, the occasions on which the forum will be called upon to enforce rights under foreign workmen's compensation acts are rare. Even if it should be otherwise, there is no need to burden the forum state's courts with the administration of foreign workmen's compensation acts. Where the forum has a commission which administers its own workmen's compensation act, the forum commission can and should administer the foreign act, whether it be commission or court administered.43 Undoubtedly enforcement by the forum's commission would still involve some extra cost because of the additional time necessary to ascertain the foreign law, but neither the extra time nor expense would seem to be so excessive as to justify denying the claimant any relief whatsoever in the forum of his choice. Where the courts of a state administer the

mitigate a claimant's difficulties in obtaining evidence from other jurisdictions, he must still bring his claim in that state whose law controls the action. Even if the necessity for a claimant to return to the jurisdiction deciding the claim is obviated by this procedure, he nonetheless is disadvantaged somewhat when the decisions of liability and extent of injury are made by administrators who have not heard the testimony or observed the claimant and who have only limited contact with those who did. In addition, if the claimant continues to reside in the state in which he seeks relief, any modification of the award could be more promptly and efficiently made when the domicile state administers the foreign act than when it merely gathers information for the state whose law is being applied.

43 Although there has been very little discussion of this possibility, the idea has been suggested. See Dwan, supra note 9, at 20. For a rejection of such commission enforcement see von Mehren \& Trautman, The Law of Multistate Problems 87-89 (1965). Also relevant are state statutes expressly authorizing the enforcement of the workmen's compensation acts of foreign states. Such statutes have rarely been used, and never to support the proposition suggested above. E.g., VT. STAT. ANN. tit. 21, § 620 (1959); IDAHo Code ANN. § 72-615 (1949); Ariz. Rev. Stat. ANN. § 23-904 (B) (1956); HawaII Rev. Laws § 97-6 (1955). See Letters from Louis Lavin, Commissioner, Vermont Department of Industrial Relations, February 9, 1966, and B. W. Oppenheim, Chairman, Idaho Industrial Accident Board, February 7, 1966, to the University of Chicago Law Review, on file in the Review office. Also, the AFL-CIO has taken no spécific position on this point. See Letter from Lawrence Smedley, Assistant Director, Department of Social Security, AFL-GIO, to the University of Chicago Law Review, March 16, 1966, on file in the Review office. For a thorough analysis of workmen's compensation administrative agencies see DODD, ADMINISTRATION OF WORKMEN'S COMPENSATTON 100-16, 214-324, 784-813 (1936). 
local workmen's compensation act, they could also enforce rights under foreign workmen's compensation acts. Problems of judicial economy would there be lessened because of the familiarity of the courts with the administration of workmen's compensation.

The Court in Crider did not decide whether a forum state's commission may apply a foreign act. Yet such administration would seem to fall within the Court's broad language that "the state of the forum may 'supplement' or 'displace' the remedy of the other State, consistently with constitutional requirements." 44

Despite constitutional permissiveness, however, it is not clear whether commissions can proceed with such administration in the absence of express authority in their statutory charters. While a few acts empower commissions to enforce an employee's rights under the act of another state if those rights can be "reasonably determined and dealt with,"45 the statutes of the majority of jurisdictions make no provision for enforcement of claims under foreign acts. Legislative omission of any provision for enförcement of rights under a foreign act need not be construed as an implied prohibition of such enforcement, since legislatures have rarely considered this issue. ${ }^{46} \mathrm{But}$ commissions have generally been regarded as tribunals of special or limited jurisdiction conferred either expressly or by necessary implication. ${ }^{47}$ Consequently, although no court has decided whether a commission can assume jurisdiction over a suit involving another state's act without express statutory authority, it is highly doubtful that commissions could or would assume jurisdiction in the absence of such authority. ${ }^{48}$

Statutory amendments may not, however, be necessary. A forum court might assume jurisdiction, on the authority of the Supreme

44380 U.S. 39, 42 (1964).

45 See statutes cited supra note 43.

46 von Mehren \& Trautman, op. cit, supra note 43 at 89. See, e.g. Letters from Samuel H. Slosberg, Director of Legislative Research, State of Maine, April 11, 1966, and W. Porter Ellington, Legislative Analyst, Department of Legislative Reference, State of Maryland, April 27, 1966, to the University of Chicago Law Review, on file in the Review office.

47 P. Bronstein \& Co. v. Hoffman, 117 N.J.L. 500, 189 A. 121 (1937) (commission held without authority to approve compromise of a valid compensation claim for less than sum prescribed by act, or of claim outside act erroneously asserted to be within its terms). See also 99 C.J.S., Workmen's Compensation § 20 (1958).

48 See, e.g., Letters from Gil Johnson, Commissioner, Department of Labor, State of Alaska, April 13, 1966, Howard M. Berg, Counsel, Industrial Accident Board, State of Delaware, April 22, 1966, and J. W. Bean, Chairman, North Carolina Industrial Commission, April 18, 1966, all to the University of Chicago Law Review, on file in the Review office, all indicating reluctance to proceed without express statutory authority. But see Letter from Leo J. Noonan, Chairman, Workmen's Compensation Commission, State of Connecticut, to the University of Chicago Law Review, April 13, 1966, on file in the Review office, indicating doubt that express statutory approval is necessary. 
Court's holding in Crider, over an action involving a foreign commission-administered workmen's compensation act and, exercising its referral power, might refer the action to the forum state's commission for determination. The availability of this alternative would depend upon court rules and state statutes governing referral. ${ }^{49}$ While courts possess inherent power to provide themselves with appropriate instruments to perform their duties, ${ }^{50}$ the power is generally limited to cases involving complicated questions of fact..$^{51}$ Where state statutes may be construed to permit referral of actions under foreign workmen's compensation acts, state courts should utilize the opportunity to refer. Such referral would be consistent with the purposes of the referral power: it would provide a less formal and more elastic method of resolving issues than is available in courts and would relieve congested courts of matters which can more competently be decided by others. ${ }^{52}$ Further, referral of foreign workmen's compensation cases would present no new procedural or administrative problem. The cost of administering the claim should be borne by the forum state. While normally a referee's costs would be paid by the losing party, the solution does not seem appropriate for a workmen's compensation claim. The chance that the claimant would have to bear the cost might deter him from bringing the complaint-a result inconsistent with the remedial purposes of workmen's compensation legislation.

The weight given to the commission's determinations should be the same as that given to determinations of a referee. Since construction of a foreign statute is involved, the court should scrutinize the commission's determination more carefully than it would have had the case

49 In many jurisdictions statutes designating the class or classes of cases which may be referred without consent of the parties, usually cases involving long accounts, have been construed to prohibit courts from making compulsory references in any matters not enumerated in the statute. E.g., Terpening v. Holton, 9 Colo. 306, 12 P. 189 (1886);. B. Roth Tool Co. v. Champ Spring Co., 146 Mo. App. 1, 123 S.W. 513 (1909); Stacey v. Milwaukee Lake Shore \& W.R., 72 Wis. 331, 39 N.W. 532 (1888). See generally Annot., 126 A.I.R. 314 (1940). Compulsory reference statutes appear to be strictly construed in actions at law because of their infringement upon the constitutional right to trial by jury. This reasoning is inapplicable, however, in workmen's compensation cases involving application of foreign law, where the parties have no right to a trial by jury or even to a hearing by the forum's courts. Consequently, state courts should feel free to refer such cases to their own workmen's compensation commission, even where not specifically authorized to do so by statute.

50 Ex parte Peterson, 253 U.S. 300 (1920) (federal district court has inherent power to appoint auditor to simplify and clarify issues and make tentative findings).

51 See, e.g., Westchester Fire Ins. Co. v. Bringle, 86 F.2d 262 (6th Cir. 1936) (in action on fire insurance policy, reference to master on extent of loss on insured engine held proper and master's findings sustained).

52 See Housing Authority v. Pezenik, 137 Conn. 442, 78 A.2d 546 (1951), where, in an action to condemn real estate, assessment of damages was referred to a committee according to statute. 
involved the local act. The need to review such determinations could effectively be met on appeal, however, and would not necessitate the court's hearing the case originally. Admittedly, enforcing rights under a foreign workmen's compensation act by utilizing the forum commission will still inconvenience the forum state somewhat, but this inconvenience is offset by the forum state's interest in affording relief to the claimant and does not, if referral is possible, warrant dismissal of the case.

\section{Substantially Similar Remedy}

Utilizing a forum state's commission to administer a foreign workmen's compensation act raises a problem which has proved most significant in the refusal of state courts to enforce rights under commission-administered foreign acts. Are the procedures and processes of the forum adequate to enforce substantive rights under a commissionadministered foreign workmen's compensation act, affording relief which is substantially similar, though not identical, to that which would be granted in the enacting state?53 Courts which have refused jurisdiction over the commission-administered workmen's compensation acts of other states because of inability to afford a reasonably similar remedy have cited as the principal reason the lack of "judicial machinery" in the forum. ${ }^{54}$ The "machinery" peculiar to commissions which has made enforcement by the courts impractical has been characterized as the capacity: (a) to conduct initial informal hearings at which the parties may attempt to reach agreement on their own; ${ }^{55}$ (b) to hear disputes in summary fashion, dispensing with many of the common law formalities; ${ }^{56}$ and (c) to supervise payments after the

53 A similar difficulty arises in federal diversity cases in which federal courts attempt to approximate results which would be reached by state courts. In determining the extent to which federal courts must defer to state law, courts have used an "outcome-determination" test. "[T] he outcome of the litigation in the federal court should be substantiall! the same, so far as legal rules determine the outcome of a litigation, as it would be if tried in a state court." Guaranty Trust Co. v. York, 326 U.S. 99, 108-09 (1945). The efforts of the federal courts to mold relief substantially similar to state court relief is discussed in 1A Moore, Federal Practice $q 0.317$ (2d ed. 1965). In a recent case, Hanna v. Plumer, 380 U.S. 460 (1965), the Court held that the service of process prescribed by the Federal Rules of Civil Procedure governs in a federal court, rather than state rules which would bar recovery. The Court in Hanna found the objectives of the "outcomedetermination" test to be "discouragement of forum-shopping and avoidance of inequitable administration of the law." 380 U.S. at 468 . Similarly, if forum commission enforcement of rights under foreign workmen's compensation acts satisfies this test, the substantial similarity problem should be no more significant than in federal diversity cases.

54 E.g., Logan v. Missouri Valley Bridge \& Iron Co., 157 Ark. 528, 249 S.W. 21 (1923); Davis v. Swift \& Co., 175 Tenn. 210, 133 S.W.2d 483 (1939).

55 Johnson v. Employers' Liability Assur. Corp., 99 S.W.2d 979 (Tex. Civ. App. 1936).

56 Davis v. Swift \& Co., 175 Tenn. 210, 133 S.w.2d 483 (1939). 
award has been made, making any adjustments necessary to meet the changed needs of the employee and insuring compliance with an award involving payments over a period of time. ${ }^{57}$ The very factors which make it impractical for courts to enforce rights under foreign commission-administered acts are, of course, the same ones which make the forum commission the body best suited to administer the foreign act. ${ }^{58}$

Relief afforded by the forum commission under a foreign workmen's compensation act would approximate the relief which would be obtained in the enacting state as closely as does relief granted whenever the courts of one state enforce rights under a foreign statute normally enforced by foreign courts. Where courts enforce transitory causes of action, the assumption is that judicial processes, while not uniform among the states, are sufficiently similar to insure that the results reached under the judicial procedure of one state will not differ significantly from those reached under the judicial procedure of any other. ${ }^{59}$ The question remains whether commission procedures are sufficiently similar to warrant the same conclusion.

An examination of the various state statutes reveals that the similarities in state commission proceedings far outweigh the differences. First, the steps for settling a contested claim are markedly similar among the states. In some states the initial hearing is conducted by the commission itself, ${ }^{60}$ but generally this duty is delegated to a referee, ${ }^{61}$ examiner, ${ }^{62}$ or member of the administering body. ${ }^{63}$ After the initial hearing, the

57 Johnson v. Employers' Liability Assur. Corp., 99 S.W.2d 979 (Tex. Civ. App. 1936).

58 Cf. 2 LARson, Workmen's Compensation 436-37 (Supp. 1965).

59 See, e.g., von MeHren \& TrautMan, op. cit. supra note 43, at 89: "[C]ourts all shate a central conception of the judicial process-the reasoned application and development of rules and principles on the basis of authoritative materials contained for the most part in statutes and prior judicial decisions. Each judicial system provides a public record of its processes of analysis and reasoning, and in every system these materials are the subject of critical discussion. These various elements make it feasible for a court of one jurisdiction to model its handling of a controversy on the treatment that the controversy would receive in the courts of another jurisdiction. Of course, an identity of result rarely, if ever, can be fully achieved. Procedural arrangements are seldom fully comparable. Attitudes of judges and of jurors, if the system uses them, are conditioned by different societies and different legal traditions."

60 E.g., ARK. Stat. ANn. § 81-1323(b) (1947); Del. Code ANn. tit. 19, § 2348 (1953); Miss. Code ANN. § 6998-24 (1942); N.C. GEN. STat. § 97-84 (1965); Wis. Stat. ANN. § 102-17 (1957).

61 E.g., Colo. Rev. Stat. ANN. § 81-14-5 (1953); MinN. Stat. § 176.381 (1961); N.J. Stat. ANN. § 34:15-53 (1959); N.Y. WORKMEN's CoMP. LAW § 150 (1965).

62 E.g., Ill. Ann. Stat. ch. 48, § 156(a) (Smith-Hurd 1960) (arbitrator); KAN. Gen. Stat. ANN. \$ 44-551 (1963); UTAH CODE ANN. § 35-I-82.52 (1953).

63 E.g., Conn. Gen. Stat. ANn. § 31-142 (1960); Idaho Code Ann. § $72-604$ (1949); ME. Rev. Stat. ANn. ch. 39, § 99 (Supp. 1963); Mass. ANn. Laws ch. 152, § 8 (1965); Mich. Stat. ANN. $\$ 17.182$ (1960). 
commission has full power to review the decision. ${ }^{64}$ Finally, the decision may be appealed to the courts, generally to a trial court ${ }^{65}$ or intermediate court of appeal, ${ }^{66}$ with the possibility of appeal to the highest court of the state. ${ }^{67}$ In some states, however, there is direct review by the highest state court. ${ }^{88}$

Secondly, commissions all operate under procedures more simplified and flexible than those typical of common law actions. ${ }^{69}$ Legislation usually provides either that administrators shall not be bound by common law or statutory rules of evidence, ${ }^{70}$ or by technical or formal procedure, ${ }^{71}$ or merely that procedure shall be as simple and summary as it reasonably may be. ${ }^{72}$

Although inevitable differences among jurisdictions have resulted from the relaxation of common law procedural standards, they are insubstantial and do not warrant the conclusion that the relief afforded by one will not approximate that afforded by another. For example, the rules established by the various state courts regarding hearsay evidence and its probative effect do not vary greatly among commissions. Hearsay evidence is admissible in the commission proceedings of all states; any differences concern the ability of such evidence to support an award. ${ }^{73}$ A majority of states require a residuum of technically admissible evidence in addition to the hearsay, while the others either permit hearsay evidence alone to support an award or reverse an award

64 E.g., Cal. LABor Code $\$ 5900$ (1964); Ga. Code ANN. § 114-708 (1956); Ilx. ANN. Stat. ch. 48, § 156(e) (Smith-Hurd 1960); Mass. AnN. Laws ch. 152, § 10 (1965); Mich. Stat. AnN. \$ 17.185 (1960); UTAF CODE ANN. \& 35-1-82.54 (1953). In some states, such as Delaware and Maine, there are no statutory provisions for administrative review, although in practice there may well be review.

65 E.g., ARK. StAT. ANN. § 81-1325(b) (1947); Colo. Rev. Stat. ANN. § 81-14-8 (1953); Ran. GeN. STAT. ANN. § 44-556 (1963).

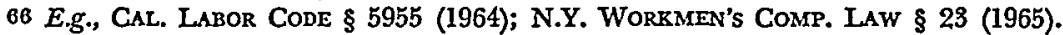

67 E.g., CAL. LABOR CODE $\S 5955$ (1964); Colo. REv. Stat. ANN. § 81-14-19 (1953); MASS. ANN. LAws ch. 152, § 11 (1965).

68 E.g., Def. Code ANN. tit. 19, § 2350 (1953); Mrch. STAt. ANN. § 17.186 (1960); Minn. STAT. § 176.471 (1961); N.C. GEN. STAT. § 97-86 (1965) (commission alone may certify questions to supreme court); UTAH CODE ANN. § 35-1-83 (1953).

69 Dodd, op. cit. supra note 37, at 225-27. See also Ross, The Applicability of Common Law Rules of Evidence in Proceedings Before Workmen's Compensation Commissions, 36 HARV. L. REV. 263 (1923).

70 E.g., Cal. Labor Code § 5708 (1964); Conn. Gen. Stat. AnN. § 31-174 (1960); Minn. STAT. \& 176.411(1) (1961); N.J. Stat. ANN. § 34:15-56 (1959).

71 E.g., ARk. Stat. ANN. § 81-1327(a) (1947); Fla. Stat. ANN. § 440.29 (1952); Md. ANN. Code art. 101, § 11 (1957); Miss. Code ANN. § 6998-28 (1942).

72 E.g., GA. CODE ANN. § II4-703 (1956); IDAHo CodE ANN. § 72-601 (1949); ILL. ANN. STAT. ch. 48, § 153 (Smith-Hurd 1960); INd. ANN. STAT. \& 40-1506 (1965); MASs. ANN. LAws ch. 152, \& 5 (1965); N.C. GEN. STAT. \& 97-80 (1965).

732 LARSON, WORKMEN'S COMPENSATION § 79.2 (1961). 
if it appears that the commission relied on the hearsay evidence and but for it would not have made the award. ${ }^{74}$ The lack of more than minor variation among these rules is explained both by the practical needs of the proceedings and by the fact that the rules are formulated under strikingly similar legislative mandates.

\section{Ascertaining Foreign Law}

Another factor in determining whether to apply a commission-administered foreign workmen's compensation act concerns the difficulty of ascertaining specialized law developed through an administrative agency of another state. It has been contended that while the judicial process is characterized by "the reasoned application and development of rules and principles on the basis of authoritative materials contained for the most part in statutes and prior judicial decisions," 75 the administrative process has no such fundamental method; that while the judicial system provides a public record of its analysis and reasoning, the administrative process tends to operate with undisclosed data and policies; and that while judicial reasoning is constantly subjected to critical discussion, the administrative process often fails to produce full or even reasoned statements of the administrator's basis for decision. ${ }^{76}$

Whatever the validity of these observations in terms of the general relationship between administrative and judicial processes, it is inaccurate to characterize the workmen's compensation law of a state as being primarily the product of the administrative process. A state's workmen's compensation law is a specialized composite of legislative, judicial, and administrative decisions. The legislative and judicial components are readily available; and that portion of the law promulgated through the administrative process is not so obscure that it cannot be ascertained by the courts or commissions of another state. First, the commission's role in deciding claims more closely approximates that of a court than it does an administrative agency:

In the spectrum of administrative agencies, ranging as they do from executive regulatory and rule-making bodies to quasijudicial tribunals deciding individual cases between particular private parties, the compensation commission while deciding controverted claims is as far toward the judicial end of the spectrum as it is possible to go without being an outright court. ${ }^{77}$

74 Ibid.

75 von MEHREN \& TRAUTMAN, op. cit. supra note 43, at 89 .

76 Ibid.

772 LARson, op. cit supra note 73, at $\S 79.90$ (1961). 
Secondly, the workmen's compensation laws of many states have been analyzed in studies undertaken by public and private groups. ${ }^{78}$

Means are available, therefore, by which a state commission might reasonably determine and administer the workmen's compensation law of another state. The commission is the body most likely to understand the intricacies of another state's workmen's compensation law, for it deals with similar problems under similar legislation. Whatever extra cost and effort might be entailed in administering the foreign law would seem to be justified by affording the claimant relief in the forum most convenient to him under the law most relevant to the action.

\section{Conclusion}

State courts have traditionally taken a mechanical approach toward enforcing rights under foreign workmen's compensation acts. If the foreign statute is commission-administered, courts have consistently declined to enforce rights under the act, holding that the relief contemplated by such an act is a "special remedy" incapable of enforcement outside the state of enactment. In Crider v. Zurich Ins. Co., however, the Supreme Court qualified any constitutional barrier to enforcement of rights under a commission-administered foreign workmen's compensation act by holding that the full faith and credit clause does not bar enforcement where the forum has an interest in the injury. The decision should initiate a re-evaluation of the grounds for dismissing multistate cases involving workmen's compensation when the forum has an interest in the injury but foreign law is found to control the action. Such a re-evaluation suggests that foreign commissionadministered workmen's compensation acts are not inherently incapable of enforcement by the forum state's courts; rather it appears the forum state's courts might assume jurisdiction over actions involving foreign acts and refer such cases to the forum state's own workmen's compensation commission for determination. The results obtained in the forum would be substantially similar to those which could be obtained in the enacting state, but the primary burden of determination would be on the forum state's commission, not its courts. Most importantly, enforcement by the forum of rights under foreign workmen's compensation acts would afford relief to the claimant in the forum of his choice-relief that is not now available.

78 E.g., Young, Workmen's Compensation LAW of OHio (1963). In addition, the Department of Labor and the national Chamber of Commerce publish informative bulletins comparing specific aspects of the various state laws. E.g., U.S. BUREAU OF LABOR Statistics, Dep'T OF LABOR, BULL. No. 206, Agricultural WORkERS AND WORKMEN'S CoMpensation (1964); U.S. ChaMrber of ComMerce, ANalysis of Workmen's Compensation LaWs (1964). 